\title{
Study of favorable conditions for shale oil and gas formation in Nenjiang Formation in south-eastern uplift area of Songliao Basin
}

\author{
SHUO DENG
}

China University Of Petroleum(Beijing)

Presenting Author: ds901007@163.com

The Songliao Basin is rich in oil shale, accounting for $96 \%$ of the total oil shale resources in northeast China. However, comparatively little research has been carried out on the rock types of the provenance, which is significantly enriched in organic matter, and their influence on the shale. To assist in unravelling its geochemical characteristics and formation mechanisms, 21 rock samples were selected from the late Cretaceous Nenjiang Formation $\left(\mathrm{K}_{2} \mathrm{n}\right)$ in the southeastern uplift of the basin.

The $\mathrm{K}_{2} \mathrm{n}$ Formation was deposited in semi-deep- and deep-lake sedimentary facies. The vitrinite reflectance of the $\mathrm{K}_{2} \mathrm{n}$ mud shale is $0.4 \sim 0.8 \%$. The TOC content of the samples is in a range of $1.44 \sim 6.03 \%$ (average $2.93 \%$ ). The $\mathrm{K}_{2} \mathrm{n}$ mud shale investigated in this study contains generally $\mathrm{I}_{-} \mathrm{II}_{1}$ type kerogen . The $\mathrm{K}_{2} \mathrm{n}$ dark mud shale was formed in a brackish, strongly reducing, algae enriched sedimentary environment. The organic sources in the mud shale were mainly aquatic organisms. The lacustrine paleoenvironment had high productivity and a large sedimentation rate. It has been suggested that the relatively high salinity and anoxic water body of $\mathrm{K}_{2} \mathrm{n}$ is a result of periodic transgression.

The provenances of the oil shale were mainly Hercynian granites. The tectonic setting of the source rocks was a continental margin orogenic belt belonging to the continental island arc volcanic series. The provenance composition of the source rock significantly affected the enrichment and hydrocarbon generation of organic matter in the source rocks. The contents of $\mathrm{CaO}, \mathrm{MnO}, \mathrm{Fe}_{2} \mathrm{O}_{3}, \mathrm{FeO}$, and $\mathrm{MgO}$ found in this study are relatively high and display a significant positive correlation with TOC. The $\mathrm{Ca}, \mathrm{Mn}$, and femic constituents would have directly or indirectly promoted biological reproduction in the lake. Therefore, it is considered that the relatively large amounts of these minerals promoted the blooming of algae, which reduced the oxygen content of the water body and was therefore beneficial for the enrichment and preservation of organic matter. At the same time, the source rock contains high levels of transition metals $(\mathrm{Cu}, \mathrm{Zn}, \mathrm{Mo}, \mathrm{Ni}, \mathrm{V})$, which played a significant role in catalysing the evolution of kerogen and thus in hydrocarbon generation. 